Original Article

\title{
Analysis of use of technological support and information content by patients with chronic obstructive pulmonary disease*
}

\author{
Análise do uso de suportes tecnológicos e conteúdos informacionais pelos pacientes com doença pulmonar \\ obstrutiva crónica
} Análisis de los diversos contenidos tecnológicos y de información para los pacientes con enfermedad pulmo-
nar obstructiva crónica

\author{
José Miguel Santos Castro Padilha1, Paulino Artur Ferreira Sousa ${ }^{2}$, Filipe Miguel \\ Soares Pereira ${ }^{3}$
}

\begin{abstract}
Objective: To identify types of technological support and information content utilized to promote therapeutic regimen management for patients with chronic obstructive pulmonary disease (COPD). Methods: In this study, which had a quantitative, exploratory, descriptive, and transversal approach, the authors used a questionnaire organized on the basis of a literature review and two models: One of acceptance of the technology and a theoretical one of the determinants for patients' perceived ease of its use. Results: The patients with COPD reported need for more information related to their daily activities and breathing exercises. Patients who had higher literacy and higher technological literacy reported that web-based technologies were more useful. Those who had lower literacy and lower technological literacy reported higher usefulness, intention and ease of use of mobile phone books, and videos in the access to information. Conclusion: Information resources may use any technological support, provided information is available according to the literacy and technological literacy of the patients and tailored to their needs.
\end{abstract}

Keywords: Pulmonary disease, chronic obstructive; Education nursing; Computer literacy; Patient education as topic

\section{RESUMO}

Objetivo: Identificar tipos de suportes tecnológicos e conteúdos informacionais utilizados na promoção da gestão do regime terapêutico em pacientes com DPOC. Métodos: Estudo de abordagem quantitativa, exploratório transversal e descritivo, tendo como recurso um questionário baseado no modelo de aceitação da tecnologia, no modelo teórico dos determinantes da percepção da facilidade de utilização da mesma e na revisão da literatura. Resultados: Os pacientes com DPOC referiram maior necessidade de informação relacionada com as atividades do dia-a-dia e com os exercícios respiratórios. Pacientes com maior literacia e maior literacia tecnológica referem maior utilidade das tecnologias Web-based; pacientes com menor literacia e menor literacia tecnológica referem maior utilidade, intenção e facilidade para a utilização do telemóvel, livros e vídeos no acesso à informação. Conclusão: Os recursos informacionais podem adotar diferentes suportes tecnológicos, desde que disponibilizados em função da literacia e literacia tecnológica e adequados às necessidades informacionais dos pacientes.

Descritores: Doença pulmonar obstrutiva crônica; Educação em enfermagem; Conhecimentos em informática; Educação de pacientes como assunto

\section{RESUMEN}

Objetivo: Identificar tipos de soportes tecnológicos y contenidos informacionales utilizados en la promoción de la gestión del régimen terapéutico en pacientes con DPOC. Métodos: Estudio de abordaje cuantitativo, exploratorio transversal y descriptivo, teniendo como recurso a un cuestionario basado en el modelo de aceptación de la tecnología, en el modelo teórico de los determinantes de la percepción de la facilidad de utilización del mismo y en la revisión de la literatura. Resultados: Los pacientes con DPOC refirieron mayor necesidad de información relacionada con las actividades del dia a dia y con los ejercicios respiratorios. Pacientes con mayor literacia y mayor literacia tecnológica refieren mayor utilidad de las tecnología Web-based; pacientes con menor literacia y menor literacia tecnológica refieren mayor utilidad, intención y facilidad para la utilización del telemóvil, libros y videos en el acceso a la información. Conclusión: Los recursos informacionales pueden adoptar diferentes soportes tecnológicos, siempre y cuando estén disponibles en función de la literacia y literacia tecnológica y adecuados a las necesidades informacionales de los pacientes.

Descriptores: Enfermedad pulmonar obstructiva crónica; Educación en enfermería; Conocimientos en informática; Educación del paciente como asunto

\footnotetext{
* Text extracted from a PhD thesis on Nursing titled "Promotion of therapeutic regimen management for patients with COPD," and submitted to the Universidade Católica Portuguesa (Portugal).

${ }^{1}$ PhD Student in Nursing. Escola Superior de Enfermagem do Porto (Portugal).

${ }^{2}$ PhD in Nursing. Escola Superior de Enfermagem do Porto (Portugal).

${ }^{3}$ PhD in Nursing. Escola Superior de Enfermagem do Porto (Portugal).
} 


\section{INTRODUCTION}

Chronic Obstructive Pulmonary Disease (COPD) is a chronic and progressive disease, whose prevalence tends to increase in the early decades of this century ${ }^{(1)}$, and it is estimated to be the third leading cause of death in $2030^{(2)}$. Its treatment is essentially based on the control of disease progression. For this purpose, developing the patient's ability to accept his/her self care in a complex therapeutic regimen is crucial.

Inclusion of the patient in the self care in this complex therapeutic regimen poses challenges to both patients and nurses. As a result, adhesion of such patients to the therapeutic regimen is lower than that of carriers of other chronic diseases ${ }^{(3,4)}$.

In view of this problem, nursing therapy and its effectiveness play a leading role.

Information therapy can facilitate the processes necessary to develop an effective therapeutic regimen management (TRM). Information therapy is defined as a timely prescription of evidence-based health information, according to specific needs of patients in order to help them make health decisions. This "involves the right information to the right person at the right time" (5).

Use of information therapy as a nursing therapeutic strategy must take into account that it can be affected by accessibility and intrinsic features of technological media (TM) and information. Moreover, it can also be affected by individual preferences (literacy or technological literacy) of learning by the patients, doubts related to the TRM, and their perceived family support for use of TM.

In view of the problem exposed above and the economic, epidemiological, and social conditions of the disease, optimization of resources in the health system is fundamental. To this end, innovation and creativity are necessary ${ }^{(6)}$ to obtain better health outcomes at lower economic, social and family costs.

In this context, availability and access to web-based technologies can enhance the effectiveness of strategies such as $e$-patient and $e$-health utilized to promote the therapeutic regimen of patients with COPD. As a result, learning of patients can be increased according to individual needs of information, in contexts and times in which they realize that information is required.

In this issue, emphasis cannot be given only to the definition of TM to be adopted. Special attention however should be given to the quality and adequacy of the information content.

Furthermore, it should be remembered that a most of the population with COPD is older than 60 years ${ }^{(1)}$. In the literature, there are indications that the internet is rarely accessed by the elderly, people with low education, and retirees ${ }^{(7)}$. Other studies report that patients with chronic disease and low health literacy have a poorer health status, lower adherence to their therapeutic regimens, and greater use of health services ${ }^{(8-14)}$.

In short, information resources and web-based technologies can help patients to both involve in their healthcare process and promote effective TRM thus enhancing their ability to make decisions and promoting self-care and adherence to treatment, and adding greater safety to the therapeutic process ${ }^{(15-17)}$. Consideration of literacy, technological literacy, health information needs of this population, and their access to technological resources (TR) is fundamental in order that information resources supported by information and communication technologies be effective in promoting TRM.

Therefore, this study was performed to identify the types of TM and information content to be used in the construction of information resources for patients with COPD. The following items were then characterized: literacy, technological literacy, availability of TR, their perceived family support in the use of TR, types of TM the subjects used in this study, and TRM areas in which patients showed a greater need for information.

\section{MATERIALS AND METHODS}

Data collection was performed using a questionnaire organized on the basis of models of technology acceptance ${ }^{(18,19)}$ and determinants of the perceived ease of use ${ }^{(20)}$ and a review of the literature on information content associated with TRM in patients with COPD.

During questionnaire construction, we had collaboration of a group of nurses $(n=52)$ who integrated a research project focused on promoting TRM in patients with COPD. A group of experts in information systems collaborated during validation of the questionnaire.

The questionnaire consisted of three sections. The first section contained characterization of health status, literacy, technological literacy, and their perceived family support. The second section contained characterization of information resources to which patients had access during evolution of their health. The third section included characterization of information needs perceived by the patients. Furthermore, utility, intention, and ease of use of different TM were also included.

Data collection was done in the period Jun-Jul 2010.

Descriptive and inferential statistics were used for data analysis, including non-parametric statistical tests. The U Mann-Whitney test was utilized to study the differences between groups and Spearman's test was utilized to study the correlations between variables.

Exploratory factorial analysis was utilized to simplify presentation of results on the information needs perceived by the patients. In this context, the method for the extraction of the main components, which could 
explain most of variance in the data set, was used. The Kaiser-Meyer-Olkin (KMO) and Bartlett's sphericity tests and the Varimax rotation method were also utilized to check adequacy of data.

The protocol of this study was approved by the Ethics Committee of the Hospital Center (Porto, Portugal), the Association for people with COPD and other chronic respiratory diseases (Porto, Portugal), and the patients involved in the study. All procedures necessary to ensure anonymity of patients and data confidentiality were used herein.

\section{RESULTS}

The mean age of the sample population $(n=108)$ was 62.4 years $(\mathrm{SD}=11.5, \max =88, \min =28)$. $\mathrm{Pa}$ tients seen in the Hospital were older $(\mathrm{p}=0.019$, mean age $=66.2, \mathrm{SD}=12.6, \max =88, \min =28$ years $)$, and differences with statistical significance between groups of men and women were not found. Regarding health status of the patients, on average, evolution of their illness lasted 15.8 years, with one hospital admission in the previous year. Seventy-eight patients reported having other diseases associated, and heart disease was the most common of them $(n=21)$. Our study indicated that the disease of older patients had more years of evolution $\left(\mathrm{r}_{\mathrm{s}} 76=0.270\right.$, $\mathrm{p}=0.05)$ and more hospital admissions in the past year $\left(\mathrm{r}_{\mathrm{s}} 72=0.272, \mathrm{p}=0.05\right)$.

To characterize literacy, three items were used regarding difficulty to read and write, and understand either text or written instruction, as assessed by the Likert three-point scale (1: much difficulty; 2: little difficulty; 3: no difficulty). A new variable (literacy) was introduced to facilitate analysis of the results. It results from arithmetic mean of the results obtained while ignoring null values in the three items. The literacy score $(p<0.001)$ of patients seen in the Association was higher (mean value $=2.94 ; \mathrm{n}=38, \mathrm{SD}=0.19)$ whereas that of patients seen in the Hospital was lower (mean value $=2.23 ; \mathrm{n}=31, \mathrm{SD}=0.51)$.

One issue (related to patients' ability to use it) was utilized to characterize their technological literacy. It was assessed by the Likert three-point scale (1: much difficulty; 2: some difficulty; 3: no difficulty) for each resource analyzed (SMS, internet, $e$-mail the nurse, the nurse's mobile phone). A new variable (technological literacy) was utilized to facilitate presentation of the results, and the arithmetic mean of the results was obtained while ignoring null values. On average, technological literacy of patients $(n=37)$ seen in the Association was higher $(2.73, \mathrm{SD}=0.32)$ than that of patients $(n=24)$ seen in the Hospital $(1.61, S D=0.57)$. In this sample, patients with higher technological literacy were younger $\left(\mathrm{r}_{\mathrm{s}} 65=-0.347, \mathrm{p}=0.01\right)$, showed higher education $\left(\mathrm{r}_{\mathrm{s}} 66=0.749, \mathrm{p}=0.01\right)$ and higher literacy $\left(\mathrm{r}_{\mathrm{s}} 75=0.688, \mathrm{p}=0.01\right)$.

Table 1 shows the availability of different TR among patients. Patients seen in the Association had more access to home phone $(p=0.044)$, mobile phone $(p=0.03)$, home internet $(\mathrm{p}<0.001)$, and $e$-mail $(\mathrm{p}<0.001)$ than patients seen in the Hospital.

Table 1. Availability of technological resources to patients with COPD seen in the Hospital Center and in the Association for people with COPD in the period Jun-Jul 2010, (N=108)

Fonte dos dados

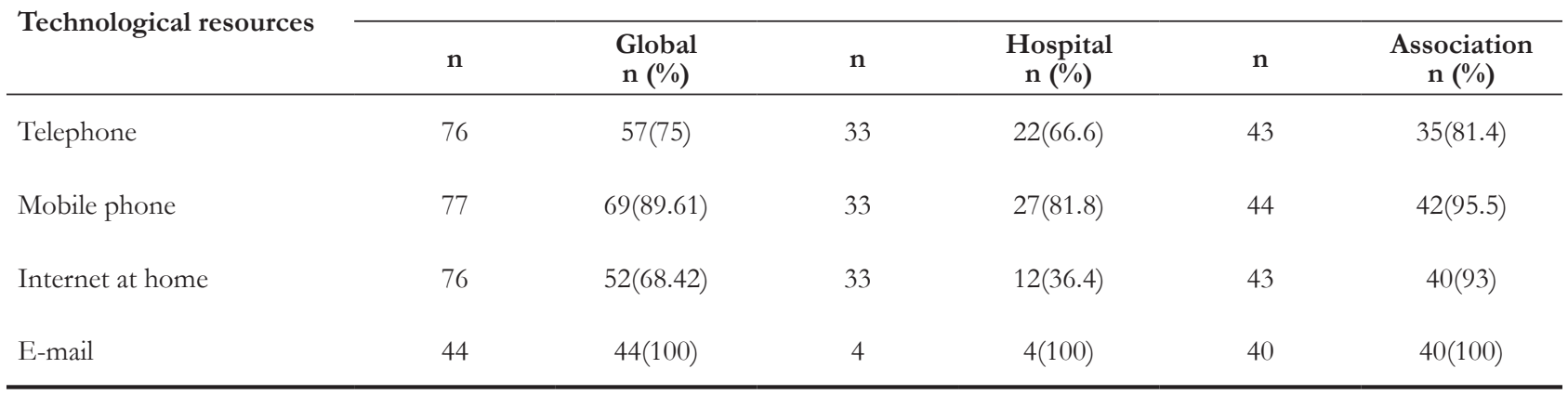

Statistically significant differences were not observed between groups of patients in their perceived recreation during the use of personal computers and the internet $(p=0.214)$. However, reports of frightening sensation when using computer and internet were higher among patients seen in the Hospital $(p=0.033)$. Patients seen in the Association used the internet $(\mathrm{p}=0.022)$ more frequently for leisure activities and seeking information on their health condition $(p<0.001)$. They also reported a greater acceptance of the internet to seek health information.

Regarding access to information resources, significant differences were observed between the sample groups during the course of the disease, and patients seen in the Association showed more access that those 
seen in the Hospital. In this sample, it was shown that patients with higher education $\left(\mathrm{r}_{\mathrm{s}} 74=0.698, \mathrm{p}=0.01\right)$, higher literacy $\left(\mathrm{r}_{\mathrm{s}} 72=0.647, \mathrm{p}=0.01\right)$, and higher technological literacy $\left(\mathrm{r}_{\mathrm{s}} 64=0.626, \mathrm{p}=0.01\right)$ had more access to information resources during the course of their illness.

In both groups, it was also found that patients perceived availability of family support in the use of SMS, internet and $e$-mail. Statistically significant differences between them were not observed.

To simplify presentation of data on information needs related to the TRM, we performed an exploratory factorial analysis, using the method for extraction of the main components $(K M O=0.844$; Bartlett's sphericity test $=0)$ and the Varimax rotation method. This analysis showed that four of the identified factors explained $83.28 \%$ of the total variance. Each of the factors identified originated a new variable that resulted from the average of the results obtained while ignoring null values. The first factor includes information needs related to the environmental conditions before going out, how to climb stairs, how to bathe expending less effort, how to organize daily activities, what to eat, how often to eat, and how to prepare food. This factor was named management of daily activities, and explains $60.28 \%$ of the total variance.

The second factor includes information needs related to the physical exercises more suitable to their health condition, namely, how to achieve them, usefulness of exercises to their health condition, the most appropriate time, and the ideal frequency for its performance. Thus, this factor was called physical exercise which explains $10.28 \%$ of total variance.

The third factor included the information needs related to the following questions: what are the medicines for, what is the most appropriate time to take them, how to take them, how to renew the medical prescription how to use the inhaler, and how to inhale according to the technique. This factor was called medication regimen, which explains $7.88 \%$ of the total variance.

The fourth factor included the information needs related to the following questions: what to do to control dyspnea, when put into practice the techniques that help control dyspnea, how to perform the techniques, and what to do to control fear. This factor was named management of dyspnea, which explains $4.90 \%$ of the total variance.

Each group of these issues, which is at the origin of the factors identified, was assessed using a Likert threepoint scale (1: no doubt; 2: some doubts; 3: many doubts).

Similarly to the previous analyzes, the U-Mann-W bitney test was utilized to analyze the differences between both sample groups. It showed that patients in the group seen in the Hospital reported greater information needs (Table 2).

Table 2. Mean and standard deviation of information needs by factor, and differences between groups.

\begin{tabular}{lcccc}
\hline Factors & Mean & DP & u-Mann-Whitney & \multicolumn{2}{c}{ Mean values } \\
\cline { 4 - 5 } Management of daily activities & 1.97 & \pm 0.68 & 0.024 & 32.56 \\
\\
Physical exercise & 2.08 & \pm 0.842 & 0.003 & 34.32 \\
Medication regimen & 1.42 & \pm 0.54 & $<0.001$ & 38.06 \\
& & & & 21.69 \\
Management of dyspnea & 1.91 & \pm 0.78 & 0.009 & 33.12 \\
\hline
\end{tabular}

In each group of doubts (Table 3), the patients were asked about perceived usefulness, intention, and ease of use of different media (Book/pamphlet, video, internet site, nurse $e$-mail, photos/images, meeting with other patients, nurse mobile phone number) by means of the Likert three-point scale (1: nothing useful; 2: somewhat helpful; 3: very useful).

The study of correlation between the variables under analysis, by using the Spearman test, identified that patients, who reported greater information needs, showed less education ( $\left.\mathrm{r}_{\mathrm{s}} 66=-0.284, \mathrm{p}=0.05\right)$, lower literacy $\left(\mathrm{r}_{\mathrm{s}} 66=-0.284, \mathrm{p}=0.05\right)$, and a lower technological literacy $\left(\mathrm{r}_{\mathrm{s}} 56=-0.367, \mathrm{p}=0.01\right)$. Older patients showed lower perceived usefulness $\left(\mathrm{r}_{\mathrm{s}} 65=-0.328\right.$, $\mathrm{p}=0.01)$, intention $\left(\mathrm{r}_{\mathrm{s}} 65=-0.340, \mathrm{p}=0.01\right)$, and ease of use $\left(\mathrm{r}_{\mathrm{s}} 65=-0.345, \mathrm{p}=0.01\right)$ of all TM. This analysis also showed that the higher the patients' education, the greater their perceived usefulness $\left(\mathrm{r}_{\mathrm{s}} 66=0.350\right.$, $\mathrm{p}=0.01)$, intention $\left(\mathrm{r}_{\mathrm{s}} 66=0.411, \mathrm{p}=0.01\right)$, and ease of use of TM $\left(\mathrm{r}_{\mathrm{s}} 66=0.602, \mathrm{p}=0.01\right)$. Patients with higher literacy showed higher perceived usefulness $\left(\mathrm{r}_{\mathrm{s}} 64=0.520\right.$, $\mathrm{p}=0.01)$, intention $\left(\mathrm{r}_{\mathrm{s}} 64=0.564, \mathrm{p}=0.01\right)$, and ease of use of TM $\left(\mathrm{r}_{\mathrm{s}} 64=0.622, \mathrm{p}=0.01\right)$. Patients with higher technological literacy also showed higher perceived usefulness ( $\mathrm{r}_{\mathrm{s}} 56=0.317, \mathrm{p}=0.01$ ), intention ( $\mathrm{r}_{\mathrm{s}} 56=0.307$, $\mathrm{p}=0.01)$, and ease of use of TM $\left(\mathrm{r}_{\mathrm{s}} 56=0.377, \mathrm{~s}=0.01\right)$. 
Table 3. Description of utility, intention, and ease of use of different media, and differences observed between patients with COPD who were seen in the Hospital or in the Association for people with COPD.

\begin{tabular}{|c|c|c|c|c|c|}
\hline & \multirow{2}{*}{ Mean } & \multirow{2}{*}{ DP } & \multirow{2}{*}{$\begin{array}{l}\text { U-Mann-Whitney } \\
\text { Valor de p }\end{array}$} & \multicolumn{2}{|c|}{ Média } \\
\hline & & & & Hospital & Associação \\
\hline \multicolumn{6}{|l|}{ Usefulness perceived } \\
\hline Book & 2.58 & \pm 0.64 & 0.504 & 29.26 & 32.02 \\
\hline Mobile phone & 2.52 & \pm 0.72 & 0.028 & 34.61 & 25.48 \\
\hline Vídeo & 2.25 & \pm 0.79 & 0.016 & 25.77 & 36.28 \\
\hline Meeting & 2.13 & \pm 0.88 & 0.013 & 25.67 & 36.41 \\
\hline Site on the internet & 2.04 & \pm 0.87 & $<0.001$ & 19.25 & 42.74 \\
\hline Photos and images & 2.03 & \pm 0.88 & 0.001 & 23.85 & 38.63 \\
\hline E-mail & 1.89 & \pm 0.84 & $<0.001$ & 20.83 & 40.87 \\
\hline \multicolumn{6}{|l|}{ Intentions expressed } \\
\hline Book & 2.53 & \pm 0.67 & 0.041 & 26.70 & 35.15 \\
\hline Mobile phone & 2.53 & \pm 0.73 & 0.11 & 33.41 & 26.94 \\
\hline Vídeo & 2.23 & \pm 0.82 & 0.003 & 24.74 & 37.54 \\
\hline Meeting & 2.06 & \pm 0.88 & 0.005 & 25.02 & 37.20 \\
\hline Site on the internet & 2.01 & \pm 0.92 & $<0.001$ & 18.91 & 44.67 \\
\hline Photos and images & 1.97 & \pm 0.89 & $<0.001$ & 22.76 & 39.96 \\
\hline E-mail & 1.85 & \pm 0.89 & $<0.001$ & 20.27 & 43.00 \\
\hline \multicolumn{6}{|l|}{ Ease of use } \\
\hline Book & 2.57 & \pm 0.63 & 0.001 & 24.32 & 38.06 \\
\hline Mobile phone & 2.57 & \pm 0.66 & 0.980 & 30.45 & 30.56 \\
\hline Vídeo & 2.35 & \pm 0.79 & $<0.001$ & 24.14 & 38.28 \\
\hline Photos and images & 2.14 & \pm 0.89 & $<0.001$ & 22.29 & 40.54 \\
\hline Meeting & 2.08 & \pm 0.85 & 0.018 & 25.85 & 36.19 \\
\hline Site on the internet & 2.06 & \pm 0.93 & $<0.001$ & 19.03 & 44.52 \\
\hline E-mail & 1.95 & \pm 0.92 & $<0.001$ & 19.42 & 44.04 \\
\hline
\end{tabular}

\section{DISCUSSION}

In this study, the authors found that patients seen in the Hospital are older than those seen in the Association. These data are similar to those described in other studies ${ }^{(8-14)}$, which also report that patients with chronic disease and poor health literacy have worse health status, lower adherence to their treatment regimen, and greater use of health services. This fact justifies the methodological approach adopted for sample selection in this study.

Technological literacy characteristics of the sample in this study coincides with the data provided the study of the Lisbon Internet and Networks Institute (7), which points to an increased use of the internet by the population who is younger and with higher academic education.

In the analysis of utility, intention, and ease of use of TM, the authors found that these groups have the same behavior regarding usefulness they perceive in the use of books. Moreover, it was identified that patients seen in the Association (younger and with higher literacy and technological literacy) were those who attributed greater utility for the use of other TM in the access to information content related to management of the treatment regimen. Regarding intention of the patients to use resources, we have found that both groups behave similarly regarding their intention to use the nurse's phone in the access to information, and those seen in the Association reported a higher intention to use other TM in the access to infor- 
mation. This fact is also recognized in the study of the Lisbon Internet and Networks Institute ${ }^{(7)}$, who pointed out that mobile phone is the equipment of information and communication technology of more widespread ownership (88.7\%) after television. These data suggest that older patients may show higher intention in using TM that favor personal interaction (e.g., mobile phone), since such devices assure them greater selfconfidence. This is also emphasized in other studies ${ }^{(21-22)}$.

It is worth mentioning the low value assigned by patients seen in the Association regarding access to information with the nurse's mobile phone, and their preference for web-based technologies. However, patients seen in the Hospital preferred to access information through nurse's mobile phone books and videos, and the low value assigned to web-based technologies emerged. These data can be related to low technological literacy and low access to different TM ${ }^{(21)}$.

In this study, the data allowed to verify that older patients, with less education, showed lower literacy, lower technological literacy, and lower access to TR. However, they realize availability of family support to help them use different TM. These patients, who showed higher need for information, also showed lower perceived usefulness, intention, and ease of use of TM, as well as, lower access to information resources during the course of the disease. Due to the patients' perceived family support, the development of web-based technology (as a resource in promoting management of their therapeutic regimen) should be focused on their skills, the level of literacy and technological literacy of the family, and their own preferences for access to information.

On the other hand, younger patients showed higher education, higher both literacy and technological liter-

\section{REFERENCES}

1. Global Initiative for Chronic Obstructive Lung Disease (GOLD). Global strategy for the diagnosis, management, and prevention of chronic obstructive pulmonary disease. Harbor (WA): Medical Communications Resources; 2009.

2. World Health Organization. World health statistics 2008. Geneva: World Health Organization; 2008.

3. Rand CS. Patient adherence with COPD therapy. Eur Respir Rev. 2005; 14(96):97-101.

4. Restrepo RD, Alvarez MT, Wittnebel LD, Sorensen, Wettstein R, Vines L, et al. Medication adherence issues in patients treated for COPD. Int J Chron Obstruct Pulmon Dis. 2008; 3(3): 371-84.

5. Mettler M, Kemper DW. Information therapy: The strategic role of prescribed information in disease self-management. Stud Health Technol Inform.2006; 121:373-83.

6. Barros AL, Carneiro CS, Batista VB. Health education: a field of action and clinical research in nursing [editorial]. Acta Paul Enferm. 2011; 24(2):ix-x.

7. Lisbon Internet and Networks Institute. A utilização de internet em Portugal 2010 [Internet]. 2010 [citado 2011 Feb 9]. Disponível em: http://www.umic.pt/images/stories/ acy, greater access, and use of different TR, especially the web-based ones, both for fun and to seek health information. This observation may be at the origin of the reference by these patients of a greater access to information resources during the course of the disease, which can be determinant for their perception of lower information need. Greater utility, intention, and perceived ease of use of all TM was also identified by the patients, although they expressed preference for use of web-based technologies. It was also observed that daily activities and physical exercise were the items in which patients had more doubts, and they were more frequent in patients seen in the Hospital.

\section{CONCLUSION}

This study contributed to define TM and content of information resources that must be developed to promote an effective TRM in patients with COPD. Information content, such as books, phone, and video, should be available for older patients, with both low literacy and low technological literacy. Information provided by means of web-based resources may facilitate promoting TRM of these patients with support of persons with whom they live.

Nurses can use any of the types of TM analyzed above, mainly web-based technology, as a resource of choice in promoting TRM for patients with higher literacy, higher technological literacy, and younger age.

\section{ACKNOWLEDGEMENTS}

The authors acknowledge the special contribution of the Association for people with COPD and other chronic respiratory diseases (http://www.respira.pt).
noticias/Relatorio_LINI_UMIC_InternetPT.pdf

8. Centre for Health Care Strategies. Factsheets [Internet]. Lawrenceville (NJ): Centre for Health Care Strategies [cited 201010 May]. Available from: http://www.chcs.org/ usr_doc/Health_Literacy_Fact_Sheets.pdf

9. Roberts NJ, Ghiassi R, Partridge MR. Health literacy in COPD. Int JCOPD. 2008;3 (4):499-507.

10. Schillinger D, Grumbach K, Piette J, Wang F, Osmond D, Daher C, Palacios J, et al. Association of health literacy with diabetes outcomes. JAMA. 2002; 288(4):475-82.

11. Williams MV, Baker DW, Honig EG, Lee TM, Nowlan A. Inadequate literacy is a barrier to asthma knowledge and self-care. Chest. 1998; 114(4):1008-15.

12. Williams MV, Baker DW, Parker RM, Nurss JR. Relationship of functional health literacy to patients' knowledge of their chronic disease. A study of patients with hypertension and diabetes. Arch Intern Med. 1998; 158(2):166-72.

13. Baker DW, Parker RM, Williams MV, Clark WS, Nurss J. The relationship of patient reading ability to self-reported health and use of health services. Am J Public Health. 1997; 87(6):1027-30. 
14. Baker DW, Parker RM, Williams MV, Clark WS. Health literacy and the risk of hospital admission. J Gen Intern Med. 1998; 13(12):791-8.

15. Weiss BD, Hart G, McGee DL, D’Estelle S. Health status of illiterate adults: relation between literacy and health status among persons with low literacy skills. J Am Board Fam Pract.1992; 5(3):257-64.

16. Grim M, Hortz B, Petosa R. Impact evaluation of a pilot web-based intervention to Increase physical activity. Am J Health Promot. 2011; 25(4):227-30..

17. Wantland DJ, Portillo CJ, Holzemer WL, Slaughter R, McGhee EM. The effectiveness of Web-based vs. non-Web-based Interventions: A meta-analysis of behavioral change outcomes. J Med Internet Res [Internet]. 2004 [cited 2011 Feb 8];6(4):e40. Available from: http:/ /www.jmir.org/2004/4/e40/
18. Davis D. A technology acceptance model for empirically testing new end-user information systems: theory and results [dissertation]. Cambridge (MA): Sloan School of Management, Massachusetts Institute of Technology; 1996.

19. Davis FD. Perceived usefulness, perceived ease of use, and user acceptance of information technology. MIS Q. 1989; 13(3): 319-39.

20. Venkatesh V. Determinants of perceived ease of use: Integrating control, intrinsic motivation, and emotion into in the technology acceptance model. Inform Sys Res. 2000; 11( 4): pp.342-65.

21. Charness N, Boot WR.Aging and information technology use potential and barriers. Curr Dir Psychol Sci. 2009;18(5): 253-8.

22. Cashen MS, Dykes, P, Gerber, B. eHealth technology and Internet resources:barriers for vulnerable populations. J Cardiovasc Nurs.. 2004; 19(3): 209-14. 